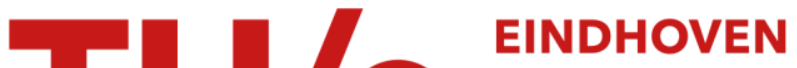 UNIVERSITY OF TECHNOLOGY
}

\section{Stratification effects in the short and long term storage of solar heat}

Citation for published version (APA):

Fischer, L. S., Dijkmans, A. P. G., \& van Koppen, C. W. J. (1978). Stratification effects in the short and long term storage of solar heat. In F. de Winter, \& M. Cox (Eds.), Sun : mankind's future source of energy : proceedings of the International Solar Energy Society congress, New Delhi, January 1978 (pp. 554-558). Pergamon.

Document status and date:

Published: 01/01/1978

\section{Document Version:}

Publisher's PDF, also known as Version of Record (includes final page, issue and volume numbers)

\section{Please check the document version of this publication:}

- A submitted manuscript is the version of the article upon submission and before peer-review. There can be important differences between the submitted version and the official published version of record. People interested in the research are advised to contact the author for the final version of the publication, or visit the $\mathrm{DOI}$ to the publisher's website.

- The final author version and the galley proof are versions of the publication after peer review.

- The final published version features the final layout of the paper including the volume, issue and page numbers.

Link to publication

\section{General rights}

Copyright and moral rights for the publications made accessible in the public portal are retained by the authors and/or other copyright owners and it is a condition of accessing publications that users recognise and abide by the legal requirements associated with these rights.

- Users may download and print one copy of any publication from the public portal for the purpose of private study or research.

- You may not further distribute the material or use it for any profit-making activity or commercial gain

- You may freely distribute the URL identifying the publication in the public portal.

If the publication is distributed under the terms of Article 25fa of the Dutch Copyright Act, indicated by the "Taverne" license above, please follow below link for the End User Agreement:

www.tue.nl/taverne

Take down policy

If you believe that this document breaches copyright please contact us at:

openaccess@tue.nl

providing details and we will investigate your claim. 
Prof.ir, C.W.J, van Koppen Professor for Heat Technology Dept. Mech. Engng.

Eindhoven Univ, of Techn. Eindhoven, Holland.

\author{
Ir. L.S. Fischer \\ $\mathrm{Sr}$. Res. Officer \\ Dept. Mech. Engng. \\ Eindhoven Univ, of Techn. \\ Eindhoven, Holland.
}

\author{
Ir. A. Dijkmans \\ now at Pechiney Nederland \\ VIissingen, HoIland.
}

\section{INTRODUCTION}

The application of thermally stratified storage forms part of a broader strategy, which can be shortly described as the conservation of exergy. Exergy (or available energy) in the strict thermodynamic sense of the word refers to the amount of work that can be obtained from a given amount of heat at a given temperature level and a given ambient heat sink temperature. In a more general sense the concept of exergy points to the quality or usefuliness of heat. For the preparation of hot water as such this quality obviously becomes zero when the heat-carrier has a temperature of some $345 \mathrm{~K}\left(72^{\circ} \mathrm{C}\right)$. For space heating the lower temperature 1 imit for the usefullness of any heat equals some $295 \mathrm{~K}\left(22^{\circ} \mathrm{C}\right)$. For the preheating of fresh intake air however, any heat at a temperature higher than the atmospheric one in winter may be put to use. These simple examples bring forward two important characteristics about exergy: it depends not only on the state of the heat but also in the actual application one has in mind, and it may, at least partially, be conserved by using the heat at subsequently lower temperatures. Some examples are presented below.

\section{FORMULAE FOR THE EXERGY}

For stored heat the specific exergy (per unit of mass) can be written as:

$$
e=c\left\{\left(T-T_{r}\right)-T_{r}\left(\ln T-\ln T_{r}\right)\right\}
$$

( $c$ = specific heat, assumediy constant; $T=$ temperature of heat carrying medium, $\mathrm{Tr}_{\mathrm{r}}=$ reference temperature, i.e. temperature at which the usefullness of the heat equals zero). The derivation of (1) can be found in every modern textbook on Engineering Thermodynamics. For ratios between $T$ and $T_{r}$ near to 1 , e can be approximated by

$$
\mathrm{e} \approx 0,5 c \mathrm{~T}_{\mathrm{r}}^{-1}\left(\mathrm{~T}-\mathrm{T}_{\mathrm{r}}\right)^{2}
$$

It should be noted that $e$ is also positive when $T<T_{r}$; this situation is related to the storing of cold for cooling purposes.

Application of eq. (1) to a stratified storage with a temperature increasing Iinearly from 295 to $345 \mathrm{~K}\left(22\right.$ to $\left.72^{\circ} \mathrm{C}\right)$ shows that the exergy in such a storage is $30 \%$ higher than in a storage in which the same amount of heat is stored at a uniform temperature of $320 \mathrm{~K}\left(47^{\circ} \mathrm{C}\right)$. The reference temperature is taken as $295 \mathrm{~K}$, an average value for the required space temperature. In case of an harmonic (sinus-like) temperature increase between the same temperature limits the surplus exergy is $44 \%$.

\section{ILLUSTRATIONS AND EXTENSION OF ARGUMENTS}

The advantages of the higher exergy content of a thermally stratified storage, as compared with a uniform one, are illustrated in fig. 1. In this example the temperature and (relative) volumeflow of a heating medium are given for a stratified and a uniform storage. The medium is assumed to extract a constant amount of heat from the storage tank, at the highest temperature available therein. The heat contents of both tanks always remain equal. For the moment any heat supply to the storage tanks is left out of consideration, because it forms a non-essential complication. From fig. 1 it is clear that the heat transfer from the stratified tank takes place under much more favourable conditions. The fan or pump power and the cross section of the transport lines both can be significantly smaller than for the uniform. storage. Even if the heat from the uniform tank were extracted in a stratified way, i.e. going from bottom to top, the stratified storage would still perform considerably better. Additionally the heat in the top of the stratified storage is at such a temperature level that hot service water might be prepared from it. In case of the uniform storage this would not be possible.

Turning to the heat supply to the storage tanks it should be noted that the average temperature of solar absorber plates feeding the storage tanks would be equal in both cases. Consequently the efficiencies of the collector would be equal. The volumeflow of cooling medium through the collectors would be smaller however in the case of the stratified storage. This again would reduce the pumping power and the size of the piping. 
BARRIERS TO THE IMPLEMENTATION OF THERMALLY STRATIF IED STORAGE

In 1iterature the advantages of thermally stratified storage are of ten grossly underestimated. Apart from overlooking the operational advantages just mentioned, this misconception generally stems from three causes:

Firstly, sight is lost of the fact that the loading and extraction of heat do interact strongly, and that both should be executed in an exergy (temperature level) conserving way. Secondly, in periods in which auxiliary heating is necessary the advantages are concealed, because any loss of exergy is easily compensated for by the high temperature at which the burner provides its heat. And thirdly, the exergy conservation chain is often broken in the system distributing the heat in the house or building, by the use of outdated equipment, dating from the past decades of cheap exergy.

\section{OVERCOMING THE BARRIERS}

As regards the first cause the storage system in the Solar House of the Eindhoven University $|2|$, as depicted in Figures 2 and 3 , provides an example of the way in which both the loading and extraction of heat can be executed in an exergy conserving way. In the storage tank the temperature increases from $10^{\circ} \mathrm{C}$ in the bottom part to $60^{\circ} \mathrm{C}$ in the top part. The floating inlet device (a thin-walled, flexible plastic hose, flow velocity below $0,1 \mathrm{~m} \mathrm{~s}^{-1}|1|$ ) automatically discharges the water from the collectors at that level in the tank where the temperature is equal to the temperature of the water inside the hose. On the other hand the multiport control valve automatically selects the exhaust port of the tank at which the temperature corresponds to the momentary heat demand of the house. The low temperature in the bottom part of the tank is maintained by the fresh intake air, which itself is preheated by the heat exchange. From calculations it appears that the measures just mentioned lead to an increase of the output of the solar system of at least $15 \%$. Similar advantages of the stratified storage of solar heat in a pebble bed have recent$1 y$ been pointed out by Löf $|3|$. The performance of the Eindhoven storage is illustrated in figs. 4 and 5 ; the chosen period is typical for the change over to auxiliary heating in the Dutch climate.

\section{THE THERMALIY STRATIFTED LONG TERM HEAT STORAGE}

As pointed out before the conservation of exergy is a particular importance for the long term storage of solar heat. The reason being that in this case no ayxiliary heating is normally available to compensate for the loss of exergy.

The long term storage of solar heat in water is currently being investigated in several experimental houses (Zero Energy House; Copenhagen, Philips
Experimental House Aachen, Frank Hooper's House, (anada). Thermal stratification does not play an important role in these projects, mainly because the depth of the reservoirs is to small to maintain a thermocline for a sufficiently long period. A depth of $8-10 \mathrm{~m}$ would be required to reach a lifetime beyond half a year $|1|$. It would then be possible to apply the same devices and obtain the same advantages as described above for the short term storage in water. To illustrate this point it is worth mentioning that in the Dutch climate such a storage would raise the net heat gain of a single glazed collector with a spectral selective absorber coating to $400 \mathrm{kWh} /$ $\mathrm{m}^{2} \mathrm{yr}$. Some $15 \%$ of this amount is due to the stratification. The heat gain just mentioned is about twice the heat gain obtainable with a short term storage. The costs of a long term storage in water are much too high however to turn such a scheme into an economically viable proposition.

The cheapest seasonal storage proposed up to now $|4|$ is the storage in the ground depicted in figure 6. This type of storage is appropriate for regions covered with thick layers of soft saturated soil and with 1 imited ground water velocities. The investment for the storage has been calculated to 1 ie well below Dfl $1,-/ \mathrm{kWh}$ thermal capacity. The lay-out of this storage, particular$1 \bar{y}$ the thick insulating cover on top (thermal resistance $10 \mathrm{~m} 2 \circ \mathrm{C} \mathrm{W}^{-1}$ ) automatically leads to thermal stratification. A simplified model of the temperature distribution in fully loaded conditions is presented in figure 7. In order to make proper use of the thermal stratification it is essential that the flow velocities in the heat transfer pipes should be kept low, typically some millimeters per second. The hot water coming from the collectors gradualiy loses its heat to the soil surrounding the pipes. At the bottom end of the pipe an inner return pipe takes the cold water back to the surface (and further to the collector). It can easily be shown that at a given level in the ground the average temperature difference between the water and the soil does not surpass $10^{\circ} \mathrm{C}$, if only the mutual distance between the heat transfer pipes is kept below some 1,5 meters. (data for the soil: thermal conductivity $1,5 \mathrm{~W} \mathrm{~m}^{-1}$ ${ }^{\circ} \mathrm{C}^{-1}$, thermal capacity $1200 \mathrm{~J} \mathrm{~kg}^{-1}{ }^{\circ} \mathrm{C}^{-1}$, density $1600 \mathrm{~kg} \mathrm{~m}^{-3}$ ) This 1 imit to the temperature difference is also valid for the extraction of the heat in the winter-period. The direction of flow in the pipes is reversed in this period.

Table 1 gives some more data on the seasonal storage for a thermal capacity of $750.000 \mathrm{kWh}$. The parameters are the depth and the diameter of the cylindrical part of the storage. The last two columns give the total length of the heat transfer pipes and the number of pipes.

The ways in which the exergy is conserved in the storage is obviously by making use of the thermal stratification which establishes itself as a consequence of the heat conduction, and by reducing the temperature difference between the heat transfer pipes and the soil. Although no definite results are available yet it is believed that these measures lead to an increase of the heat gain of the solar installation of the same order of 
magnitude as in the example presented earlier.

\section{CONCLUSTONS}

Examples have been presented of the exploitation of thermal stratification in the storage of solar heat. The systematic use of thermal stratification generally leads to an increase in the heat gain of solar heating installations of the order of $15 \%$. Moreover the dimensions of several components of the installation can be substantially reduced. It has been shown that the application of thermally stratified storage forms part of a broader strategy which can be shortly described as the conservation of exergy.

\section{REFERENCES}

(1) L.S. Fischer, et al., The Thermodynamics and Some Practical Aspects of Thermally Stratified Heat Storage in Water, Eindhoven Univ, of Technology, Rep. WPS3-75.11.R247 (Nov. 1975).

(2) J. Hamaker, et. a1., The Solar House of the Eindhoven University of Technology, Rep. WPS3-77.6.R281 (June 1977).

(3) G.0.G. Löf, et. al., Design of a solar heating and cooling system for CSU Solar House II, Solar Energy, 19, (1977), no. 1, pp $79-85$.

(4) A.P.G. Dijkmans, L.S. Fischer and C.W.J. van Koppen, The long term storage of solar heat in the ground, Paper 29, International Meeting on Solar Heating of Buildings and Water, Liège, 12-14 Sept. 1977.

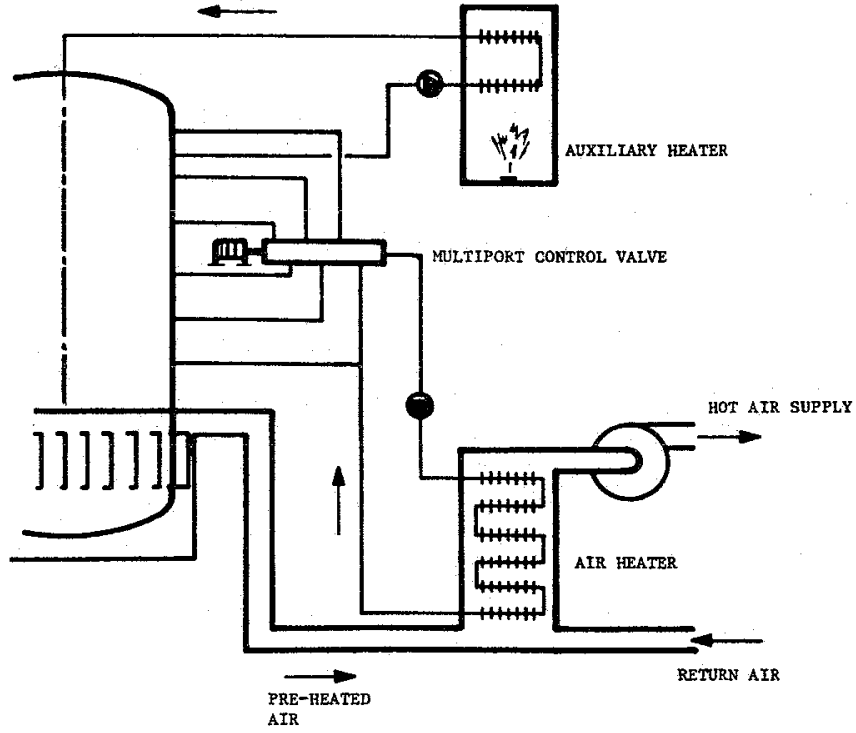

FIG. 3 AUXILIARY HEATER, HEAT SUPPLY SYSTEM AND AIR HEATER (SCHEMATICALLY).

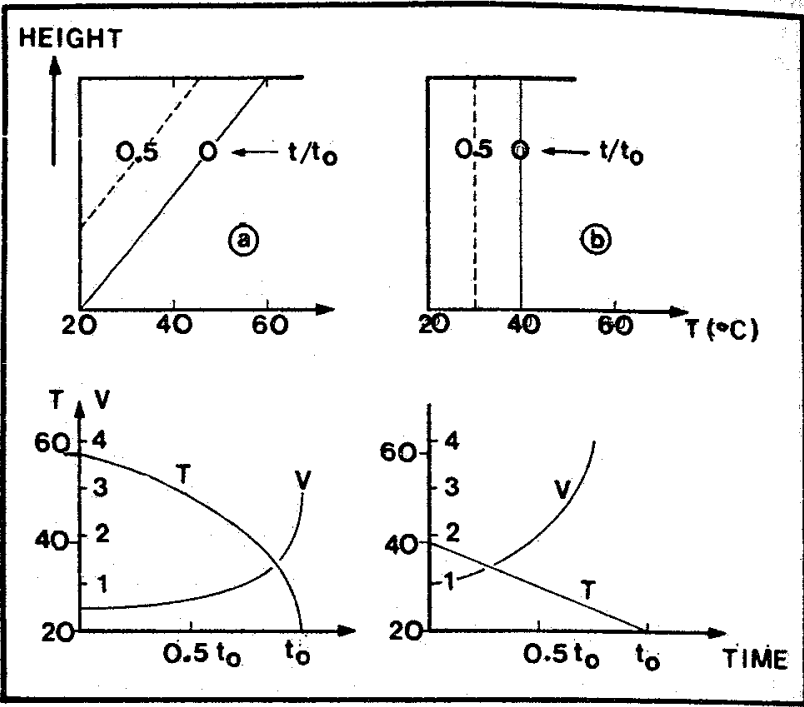

FIG. 1. TEMPERATURE (T) AND RELATIVE VOLUMEFLOW (V) OF A HEATING MEDIUM TRANSFERRING A CONSTANT AMOUNT OF HEAT FROM (THE TOP OF) $\triangle$ STRATIFIED (A) AND A UNIFORM (B) HEAT STORAGE. THE UPPER FIGURES REPRESENT THE TEMPERATURE-DISTRIBUTIONS AT THE BEGINNING AND HALF-WAY THE EMPTYING OF THE STORAGE (TOTAL $\operatorname{TIME}=t_{0}$ ).

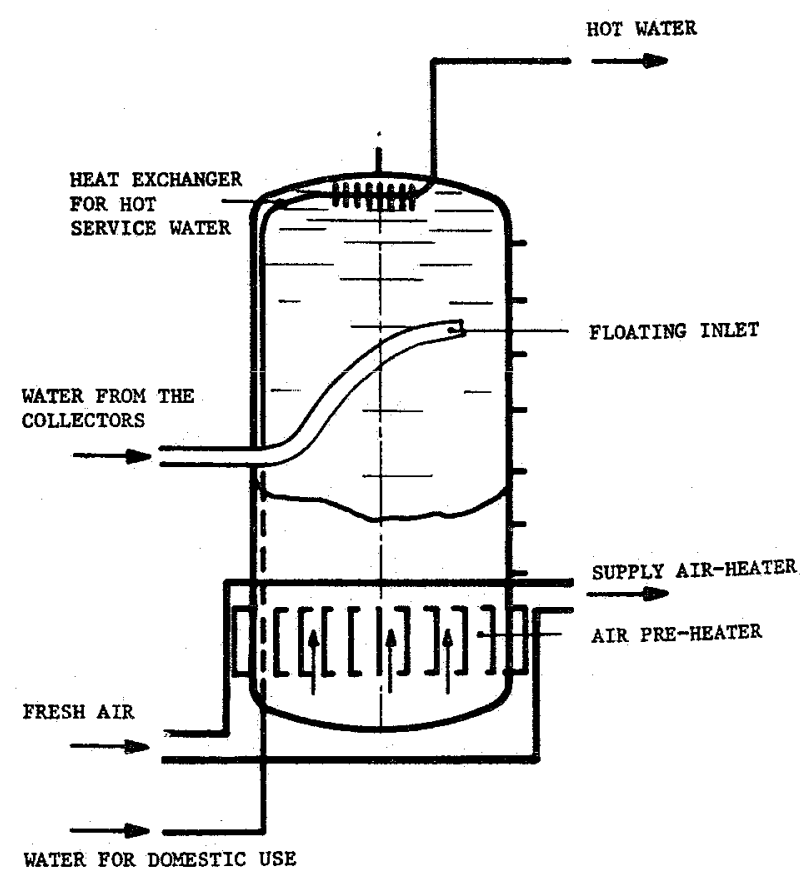

FIG. 2 SCHEME OF THE WATERTANK STORAGE WITH A FLOATING INLET, A HEAT EXCHANGER FOR HOT SERVICE WATER AND AN $\triangle I R$ PRE-HEATER 

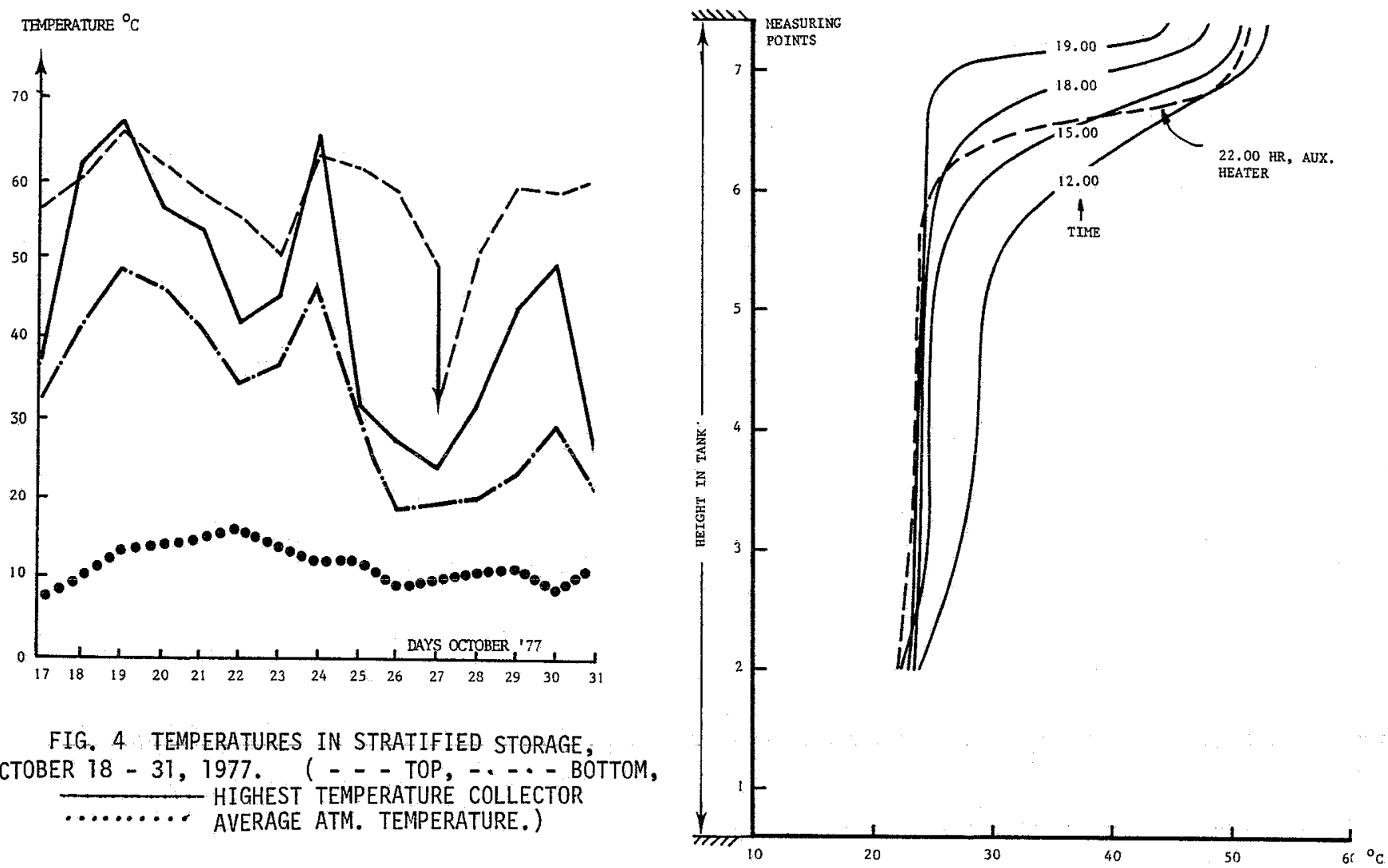

FIG. 4 TEMPERATURES IN STRATIFIED STORAGE, OCTOBER 18 - 31, 1977. ( - - TOP, - - - - BOTTOM, HIGHEST TEMPERATURE COLLECTOR AVERAGE ATM. TEMPERATURE.)

FIG. 5 STRONG THERMOCLINES IN THE STRATIFIED STORAGE ON OCTOBER 27, 1977.

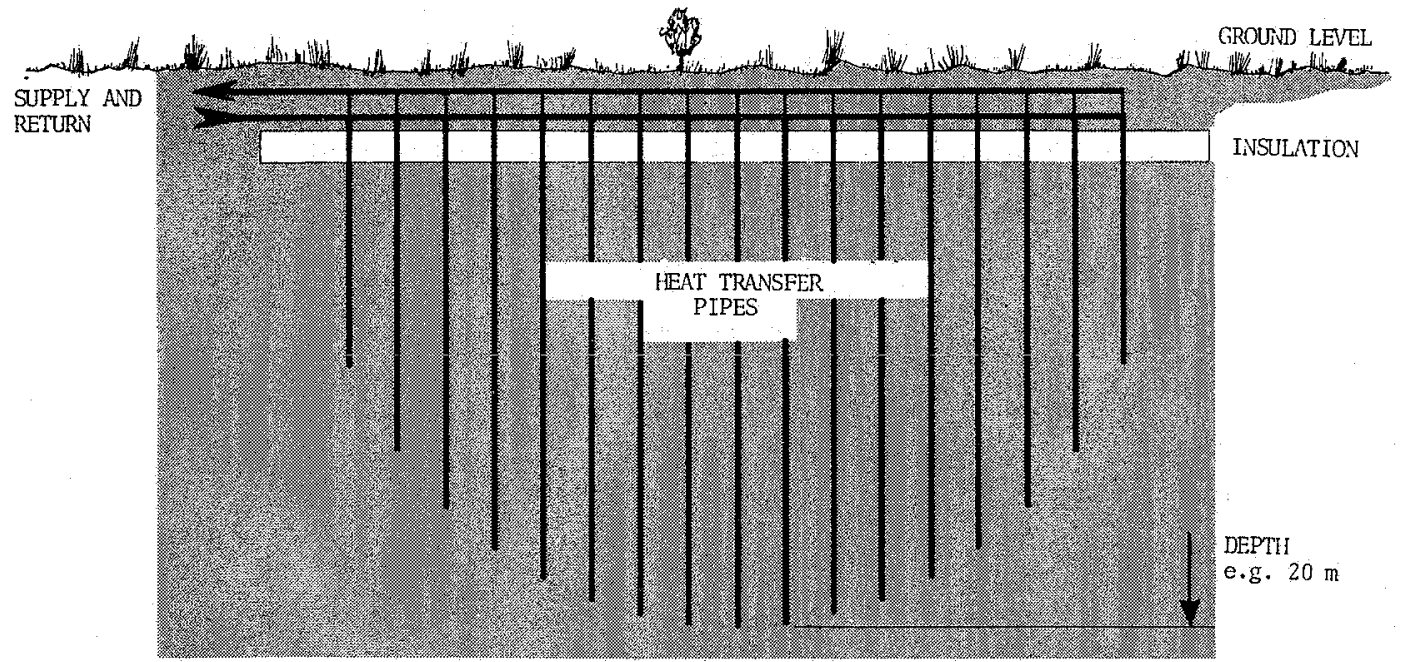

FIG. 6 GENERAL LAYOUT OF A SEASONAL STORAGE IN THE GROUND 


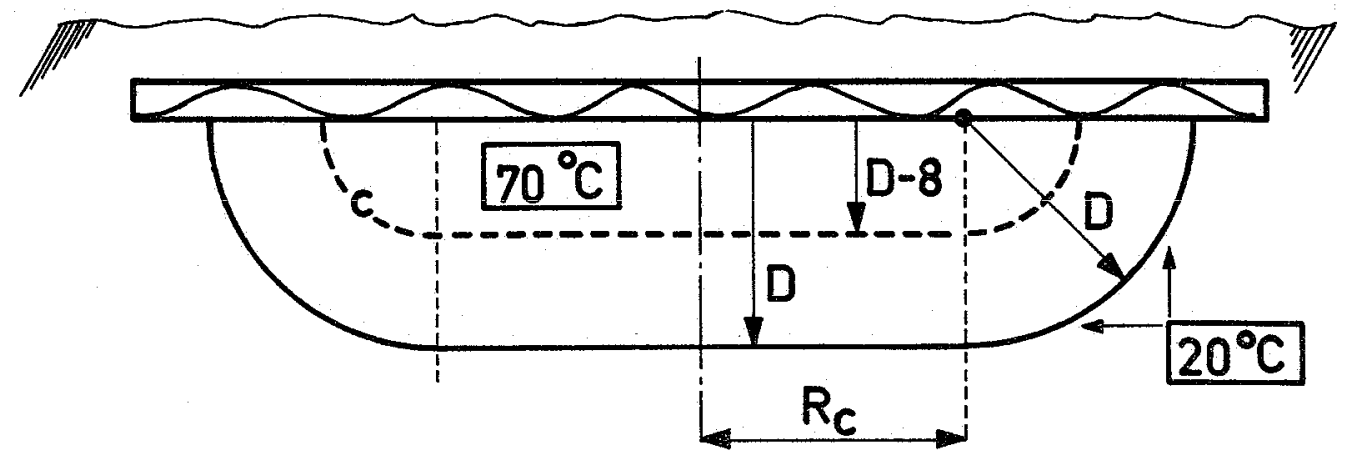

FIG. 7: SIMPLIFIED MODEL OF THE TEMPERATURES IN THE SEASONAL STORAGE (FULLY LOADED).

\begin{tabular}{|c|c|c|c|c|c|}
\hline $\begin{array}{c}\text { DEPTH } \\
\mathrm{D}\end{array}$ & $\begin{array}{c}\text { RAD.CYL. } \\
\mathrm{Rc}\end{array}$ & $\begin{array}{c}\text { HEAT } \\
\text { LOSS }\end{array}$ & EFFIC. & $\begin{array}{l}\text { LENGTH } \\
\text { PIPES }\end{array}$ & $\begin{array}{c}\text { NUMBER 0. } \\
\text { PIPES }\end{array}$ \\
\hline \hline 27 & 0 & 175.000 & 76,5 & 23,500 & 1315 \\
25 & 2.7 & 177.700 & 76,3 & 23,800 & 1380 \\
20 & 9.8 & 188.600 & 74,8 & 24,000 & 1590 \\
15 & 18.4 & 218.000 & 70,9 & 24,900 & 2000 \\
10 & 31.7 & 315.000 & 58,0 & 28,200 & 3120 \\
\hline \hline $\mathrm{m}$ & $\mathrm{m}$ & $\mathrm{kWh} / \mathrm{yr}$ & $\%$ & $\mathrm{~m}$ & - \\
\hline
\end{tabular}

TABLE I. MAIN DESIGN FEATURES AND PERFORMANCE OF A $750.000 \mathrm{KWH}$ SEASONAL STORAGE. 